\title{
THE SPEED OF EXCHANGE RATE PASS-THROUGH IN ROMANIA
}

\author{
Irina-Marilena $\mathbf{B A N}^{\mathrm{a}, *}$ \\ a) Babeș-Bolyai University, Faculty of Economics and Business Administration, \\ Cluj-Napoca, Romania
}

Please cite this article as:

Article History:

Ban, I.M., 2018. The speed of exchange rate pass- Received: 28 February 2018 through in Romania. Review of Economic Studies and Accepted: 15 April 2018 Research Virgil Madgearu, 11(1), pp.21-40.

doi: 10.24193/RVM.2018.11.19.

Abstract: Based on the monthly evolution of consumer prices and nominal effective
exchange rate from 1996 to 2017 , we investigated the speed of exchange rate pass-
through in Romania. We employed the cross-correlation function methodology,
estimating univariate GARCH models for both inflation rate and exchange rate.
The results indicate that there is only a variance causality between the variables,
meaning that nominal exchange rate fluctuations cause significant inflation rate
variations. This transmission process may baffle the efforts of policy makers in
targeting inflation for Romania. Key words: exchange rate pass-through; consumer prices; cross-correlation function; GARCH models

JEL Classification: $C_{32}$; $E_{31} ; F_{31}$; $O_{52}$

(C) 2018 Alma Mater Publishing House. All rights reserved.

* Corresponding author. E-mail address: irina.ban@econ.ubbcluj.ro. 


\section{References}

1. Bahmani-Oskooee, M.M., 2002. Do nominal devaluation lead to real devaluation in LCD's? Economics Letters, 74, pp.385-391.

2. Ban, I.M., 2009. Romania's competitive advantage before admission to the European Union. Studia Universitatis Babes-Bolyai, Oeconomica, 54(2), pp.72-89.

3. Ban, I.M., 2017. Specializarea internaţională şi avantajul competitiv. Cluj-Napoca: Presa Universitară Clujeană.

4. Ban, I.M. and Pellegrini, P., 2016. Currency devaluation and external adjustement in Romania. Review of Economic Studies and Research Virgil Madgearu, 9(2), pp.5-19.

5. Beirne, J. and Bijsterbosch, M., 2009. Exchange Rate Pass-through in Central and Eastern European Member States. ECB Working Paper, no. 1120.

6. Betts, C. and Devereux, M., 1996. The exchange rate in a model of pricing-to-market. European Economic Review, 40, pp.1007-1021.

7. Betts, C. and Devereux, M., 2000. Exchange rate dynamics in a model of pricing-to-market. Journal of International Economics, 50, pp.215-224.

8. Betts, C. and Devereux, M., 2001. The International Effects of Monetary and fiscal Policy in a Two Country Model. In: G. Calvo, R. Dornbusch and M. Obstfeld, eds. 2001. Money, Capital Mobility and Trade: Essays in Honor of Robert Mundell. Cambridge: MIT Press. pp.9-52.

9. Chari, V., Kehoe, P. and McGrattan, E., 2000. Sticky price models of the business cycle: can the contract multiplier solve the persistence problem? Econometrica, 68, pp.1151-1179.

10. Cheung, Y.W. and Ng, L.K., 1996. A causality-in-variance test and its application to financial market prices. Journal of Econometrics, 72, pp.33-48.

11. Constantinou, E., Georgiades, R., Kazandjian, A. and Kouretas, G.P., 2005. Mean and Variance Causality between the Cyprus Stock Exchange and Major Equity Markets. University of Crete Economics Working Paper, no. 05-02, [online] Available at: <https://ssrn. com/abstract $=675344>$ [Accessed 2 March 2009]. 
12. Coricelli, F., Jazbec, B. and Masten, I., 2006. Exchange rate passthrough in EMU acceding countries: Empirical analysis and policy implications. Journal of Banking and Finance, 30, pp.1375-1391.

13. Cozmâncă, B.O. and Manea, F., 2010. Exchange rate pass-through into Romanian price indices. A VAR Approach. Romanian Journal of Economic Forecasting, 3, pp.26-52.

14. Engle, R., Lilien, D. and Robins, R., 1987. Estimating Time Varying Risk Premia in the Term Structure:The Arch-M Model.Econometrica, 55(2), pp.391-407. doi:10.2307/1913242.

15. Frankel, J., Parsley, D.C. and Wei, S.J., 2005. Slow Passthrough Around the World: A New Import for Developing Countries? NBER Working paper, no. 11199.

16. Gueorguiev, N., 2003. Exchange rate pass-through in Romania. IMF Working Paper, no. WP/O3/130.

17. Jimborean, R., 2013. The exchange rate pass-through in the new EU member states. Economic Systems, 37, pp.302-329.

18. Korhonen, I., Wachtel P., 2005. A note on exchange rate passthrough in CIS countries. Research in International Business and Finance, 20, pp.215-226.

19. McCallum, B.T. and Nelson, E., 1999. An optimizing IS-LM specification for monetary policy and business cycle analysis. Journal of Money, Credit and Banking, 31, pp.296-316.

20. Nelson, D.B., 1991. Conditional Heteroskedasticity in Asset Returns: A New Approach. Econometrica, 59(2), pp.347-370.

21. Razafimahefa, I. and Hamori,S., 2007.InternationalCompetitiveness in Africa. Policy Implications in the Sub-Saharan Region. Berlin: Springer.

22. Tudor, C., 2008. Modelarea volatilităţii seriilor de timp prin modele GARCH simetrice. The Romanian Economic Journal, 30(4), pp.185-210. 